\title{
POTENSI KERUSAKAN GEMPA BUMI AKIBAT PERGERAKAN \\ PATAHAN SUMATERA DI SUMATERA BARAT DAN SEKITARNYA
}

\author{
Oleh : Hendro Murtianto*)
}

\begin{abstract}
Abstrak
Aktivitas zona patahan Sumatera bagian tengah patut mendapatkan perhatian, karena zona tersebut merupakan zona yang rawan terhadap aktivitas pergeseran sesar yang dapat berdampak pada timbulnya kerusakan yang signifikan pada lokasi strategis manusia. Tujuan dari tulisan ini adalah : 1) mengetahui persebaran daerah rawan bencana gempa bumi di Sumatera Barat dan sekitarnya akibat pergerakan patahan Sumatera bagian Tengah; 2) mengidentifikasi daerah potensial kerusakan bencana gempa bumi di Sumatera Barat dan sekitarnya akibat patahan Sumatera bagian Tengah.

Metode yang digunakan adalah analisis Sistem Informasi Geografis, dengan data sekunder berupa citra landsat, peta patahan linier, sejarah kegempaan dan kepadatan penduduk di wilayah kajian.

Hasil yang didapatkan adalah : 1) persebaran daerah rawan gempa akibat patahan Sumatera bagian tengah adalah berada di sekitar patahan, dan besar kecilnya kerusakan yang terjadi tergantung pada panjang, lebar, kedalaman hiposentrum gempa bumi, jenis batuan yang terkena gempa, besarnya pergeseran batuan (displacement), lama dari getaran gempa; 2) Daerah dengan potensial kerusakan BESAR akibat gempa bumi patahan Sumatera bagian tengah adalah pada : Solok, Padang Panjang, Bukit Tinggi,; Sedangkan Potensial kerusakan SEDANG akibat gempa bumi patahan Sumatera bagian tengah adalah pada : Muara Sijunjung, Sawah Lunto, Paya Kumbuh; dan Potensial kerusakan KECIL akibat gempa bumi patahan Sumatera bagian tengah adalah pada: Kota/Kabupaten di sebelah timur Muara Sijunjung, Sawah Lunto, Paya Kumbuh. Untuk kota di pesisir barat Sumatera, seperti Padang mempunyai tingkat kerawanan yang tinggi terhadap gempa bumi tektonik dari proses konvergen Lempeng Samudra Hindia dan Lempeng benua Eurasia dan gelombang tsunami yang dapat ditimbulkannya.
\end{abstract}

Kata Kunci : Gempa Bumi, Patahan Sumatera.

*) Hendro Murtiyanto, S.Pd., M.Si., adalah dosen Jurusan Pendidikan Geografi FPIPS UPI.

\section{Pendahuluan}

Gempa bumi adalah berguncangnya bumi yang disebabkan oleh tumbukan antar lempeng bumi, patahan aktif akibat aktivitas gunungapi atau runtuhan batuan. Kekuatan gempabumi akibat aktivitas gunungapi dan runtuhan batuan relatif kecil 
sehingga tulisan ini akan memusatkan pembahasan pada gempabumi akibat tumbukan antar lempeng bumi dan patahan aktif.

Kepulauan Indonesia terletak pada pertemuan 3 lempeng utama dunia yaitu lempeng Australia, Eurasia, dan Pasifik. Lempeng Eurasia dan Australia bertumbukan di lepas pantai barat Pulau Sumatera, lepas pantai selatan pulau Jawa, lepas pantai Selatan kepulauan Nusatenggara, dan berbelok ke arah utara ke perairan Maluku sebelah selatan. Antara lempeng Australia dan Pasifik terjadi tumbukan di sekitar Pulau Papua. Sementara pertemuan antara ketiga lempeng itu terjadi di sekitar Sulawesi. Itulah sebabnya mengapa di pulau-pulau sekitar pertemuan 3 lempeng itu sering terjadi gempabumi. Akibat utama gempabumi adalah hancurnya bangunan-bangunan karena goncangan tanah. Jatuhnya korban jiwa biasanya terjadi karena tertimpa reruntuhan bangunan, terkena longsor, dan kebakaran. Jika sumber gempabumi berada di dasar lautan maka bisa membangkitkan gelombang tsunami yang tidak saja menghantam pesisir pantai di sekitar sumber gempa tetapi juga mencapai beberapa km ke daratan.

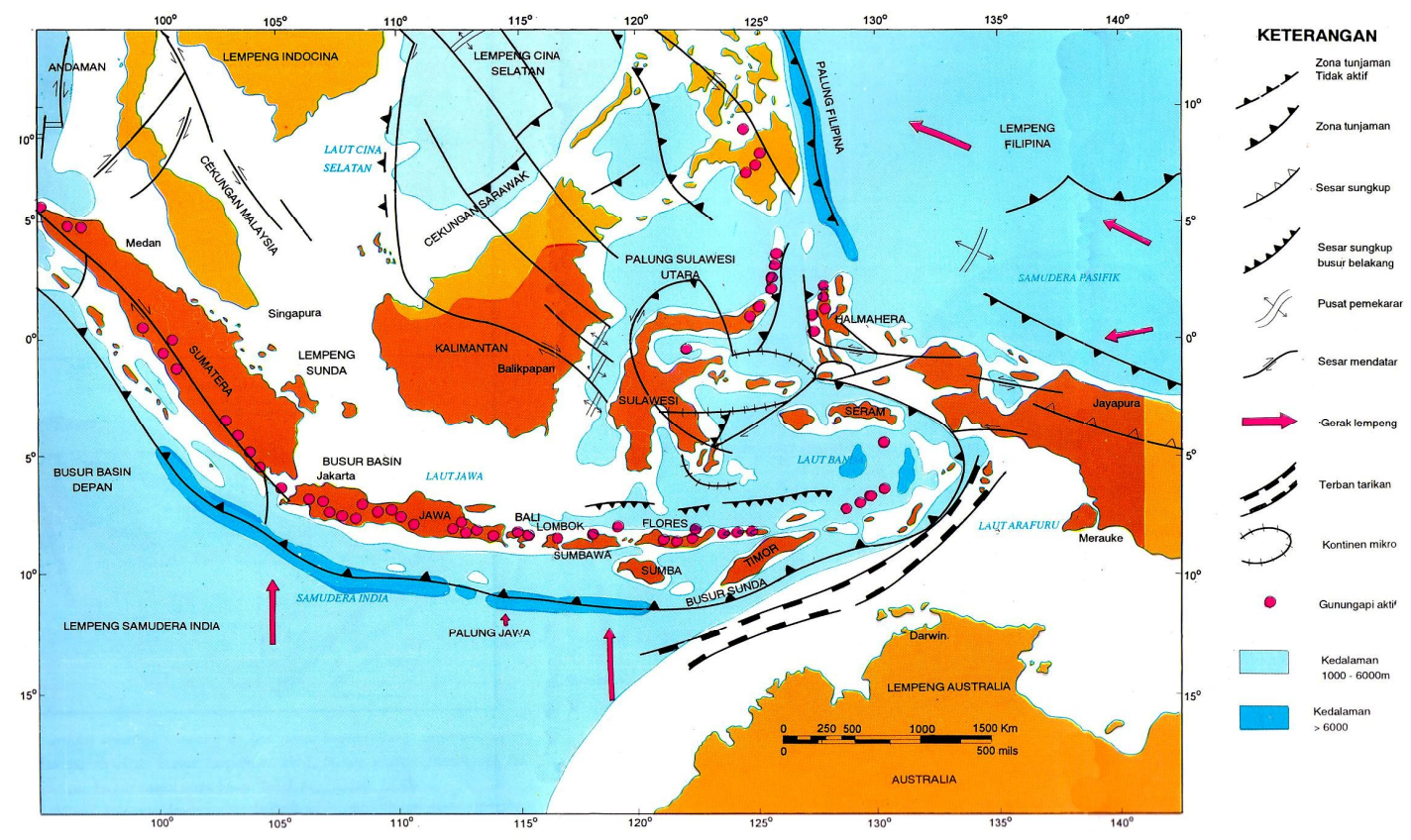

Gambar 1. Jalur lempeng tektonik di Indonesia

Data USGS (United States Geological Survey) menyebutkan bahwa terjadi gempa berkekuatan 6,3 pada skala Richter mengguncang Sumatera Barat dan sekitarnya pada hari Selasa tanggal 6 Maret 2007 pukul 10:49 WIB. Gempa susulan dengan kekuatan 6,0 skala Richter dua jam kemudian yang menyebabkan kerusakan lebih lanjut menimbulkan kepanikan di kalangan penduduk. Gempa yang berpusat $11 \mathrm{~km}$ di barat daya Batu Sangkar dengan kedalaman $23 \mathrm{~km}$ itu juga meratakan ratusan bangunan. 
Bencana gempa bumi di Indonesia memang merupakan suatu kewajaran yang terjadi, mengingat sifat geofisik, geotektonik dan volkanik yang ada di wilayah Indonesia. Bencana gempa bumi belum bisa diramalkan secara pasti oleh manusia, kapan akan terjadinya dan seberapa besar? Akan tetapi manusia tentu saja diharapkan untuk tidak menyerah dengan segala kondisi alam yang ada, sehingga timbullah berbagai macam studi mengenai gempa bumi serta mitigasi bencananya. Dalam studi geografi tentang penanganan gempa bumi salah satu sumbangannya adalah pada analisis spasial yang diterapkan pada daerah yang rawan terhadap bencana, guna manusia tetap waspada akan bencana sehingga dapat mengurangi dampak negative akibat bencana alam tersebut. Penyusunan suatu analisis spasial yang menjelaskan lokasi, kerentanan dan jalur evakuasi bencana sangat membantu bagi pola penanganan bencana yang akan diterapkan.

\section{Tujuan}

Tujuan dari penulisan makalah ini adalah :

a. Mengetahui persebaran daerah rawan bencana gempa bumi di Sumatera Barat dan sekitarnya akibat pergerakan patahan Sumatera bagian Tengah.

b. Menidentifikasi daerah kerusakan potensial bencana gempa bumi di Sumatera Barat dan sekitarnya akibat patahan Sumatera bagian Tengah.

\section{Metode}

Dalam tulisan ini digunakan beberapa instrumen guna mendukung tercapainya tujuan penulisan, yaitu:

a. Alat dan Data yang digunakan seperti, Citra Landsat Sumatera Barat dan sekitarnya; Peta Patahan Linier (geologi) yang diketahui di Sumatera Barat dan sekitarnya; Peta Kepadatan Penduduk di Sumatera Barat dan sekitarnya; Data hiposentrum gempa bumi di Sumatera Barat dan sekitarnya tanggal 6 Maret 2007; PC dengan software Arc View 3.3.

b. Langkah-langkah analisis data

1) Melakukan overlay terhadap Citra Landsat dan Peta Patahan Linier yang diketahui di Sumatera Barat dan sekitarnya.

2) Mengidentifikasi daerah di luar patahan linier Sumatera bagian Tengah yang mempunyai potensial seismic.

3) Mengidentifikasi persebaran penduduk dan kepadatannya di Sumatera Barat dan sekitarnya.

4) Mengidentifikasi daerah yang mempunyai tingkat hazard yang berkaitan dengan kerugian manusia.

5) Mengklasifikasi daerah yang mempunyai kerusakan potensial terhadap gempa bumi di Sumatera Barat dan sekitarnya.

\section{Pembahasan}

Gempa adalah sentakan atau getaran pada kerak bumi sebagai gejala pengiring cara aktivitas tektonisme, vulkanisme, maupun runtuhan bagian bumi secara local. Pada waktu gempa itu terjadi, bumi bergetar dan tempat kita 
berada mengalami guncangan, baik ke samping kiri-kanan maupun ke ataske bawah. Menurut cara terjadinya dan letak sumbernya gempa bumi dapat dibagi dalam beberapa, macam sebagai berikut.

1) Gempa vulkanik. gempa ini terjadi sebagai akibat getaran yang diakibatkan oleh letusan gunungapi. Getaran tanah hanya terasa lereng gunung atau di daerah sekitar kaki gunung.

2) Gempa tektonik. Gempa ini terjadi sebagai akibat peristiwa patahnya lapisan batuan pada lempeng tektonik. Akibat pergerakan lempeng tektonik, di dalam bumi terjadi proses geologi yang mengakibatkan tegangantegangan dan regangan-regangan. Jika tegangan dan regangan ini meningkat dan melampaui batas kekuatannya lapisan bumi tersebut patah. Akibat dari patahan, tenaga yang dikekang akhirnya lepas sebagian atau seluruhnya dalam bentuk getaran ke seluruh permukaan bumi. Getaran yang seperti ini disebut gempa bumi tektonik.

3) Gempa runtuhan. Gempa ini terjadi jika suatu gua di daerah pertambangan atau daerah batuan kapur runtuh. Akibat lapisan batuan terguncang, terjadilah getaran-getaran yang hanya dirasakan di tempat itu.

Berdasarkan letak kedalaman sumber, gempa bumi dapat digolongkan sebagai berikut:

1) Gempa dalam ialah gempa bumi yang sumbernya (hiposenter) berada lebih dari $300 \mathrm{~km}$ di bawah permukaan bumi. Di Indonesia, gempa bumi dalam umumnya berada di bawah Laut Jawa, Laut Flores, Laut Banda dan Laut Sulawesi.

2) Gempa menengah ialah gempa yang hiposenterya berada antara $60-300 \mathrm{~km}$ di bawah permukaan bumi. Di Indonesia, gempa bumi menengah terbentang sepanjang Sumatera sebelah Barat, Jawa sebelah Selatan NusaTenggara antara Sumbawa dan Maluku.

3) Gempa dangkal ialah gempa yang hiposenternya < $60 \mathrm{~km}$ dari permukaan bumi. Di Indonesia gempa bumi dangkal letaknya terpencar. Gempa ini dapat menimbulkan kerusakan besar. Makin dangkal gempa itu, maka daya perusaknya makin besar.

Faktor-faktor yang berpengaruh terhadap besar-kecilnya gempa adalah:]

1) Panjang, lebar, kedalaman hiposentrum gempa bumi

2) Jenis batuan yang terkena gempa

3) Besarnya pergeseran batuan (displacement)

4) Lama dari getaran gempa

Dari penjelasan di atas, maka dapat diketahui bahwa gempa yang terjadi di Sumatera Barat dan sekitarnya dengan lokasi hiposentrumnya $11 \mathrm{~km}$ barat daya batu Sangkar atau di utara Danau Singkarak pada tanggal 6 Maret 2007 dengan kekuatan gempa 6,3 skala Richter dan kedalaman hiposentrum $23 \mathrm{~km}$ merupakan jenis gempa tektonik dangkal, yang dapat menyebabkan kerusakan fisik. 
USGS ShakeMap : SOUTHERN SUMATRA, INDONESIA

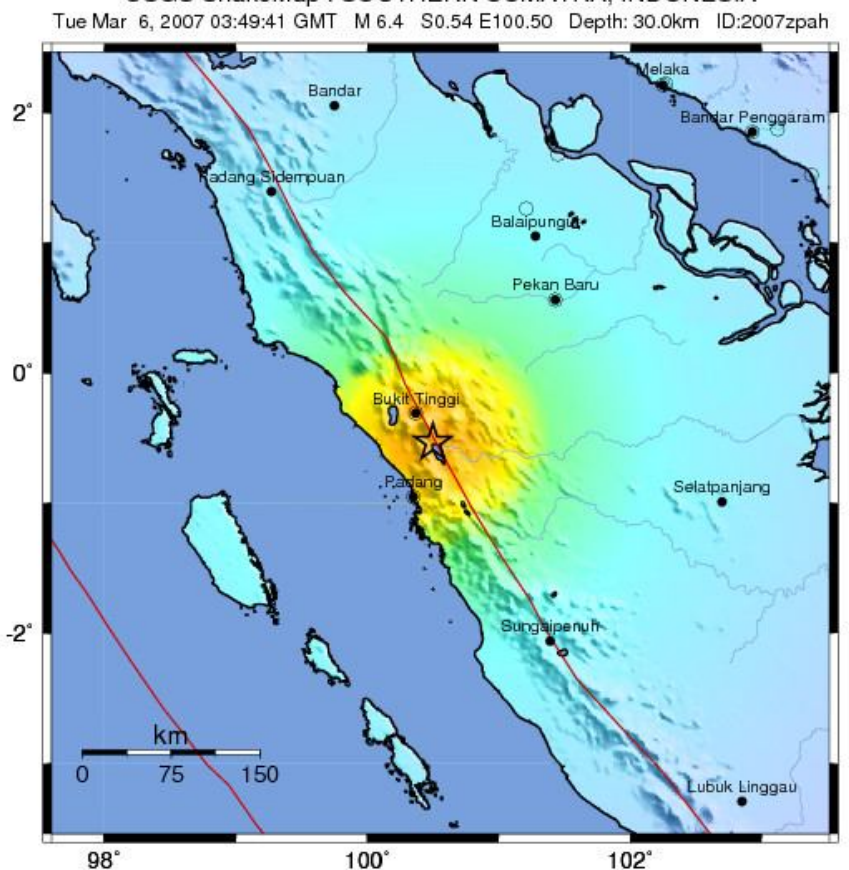

Map Version 2 Processed Tue Mar 6, 2007 10:02:21 AM MST - NOT REVIEWED BY HUMAN

\begin{tabular}{|c|c|c|c|c|c|c|c|c|c|}
\hline $\begin{array}{l}\text { PERC } \\
\text { SHA }\end{array}$ & $t$ felt & eak & Light & oderat & Strong & Very strong & Severe & folent & Extr \\
\hline 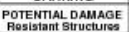 & ne & none & none & Light & Light & Moderate & oderate/Heavy & Heavy & 1. Heav \\
\hline 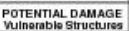 & none & nore & none & ht & Moderate & tri'Hesavy & teavy & Hescry & Hesvy \\
\hline PEAK A & $<.17$ & .17-1.4 & $7-3.8$ & 2.2 & 0.2-18 & & $34-65$ & -124 & 124 \\
\hline PEAK V & $<0$ & $0.1-1.1$ & 1.1-3.4 & 3.4 & 8.1-16 & $16-3$ & $31-60$ & $0-116$ & 116 \\
\hline $\begin{array}{l}\text { TE } \\
\text { SII }\end{array}$ & I & II- & IV & V & VI & vil & VIIII & IX & $x+$ \\
\hline
\end{tabular}

Gambar 2. Hiposentrum gempa 6 Maret 2007 dan intensitasnya di Sumatera Barat

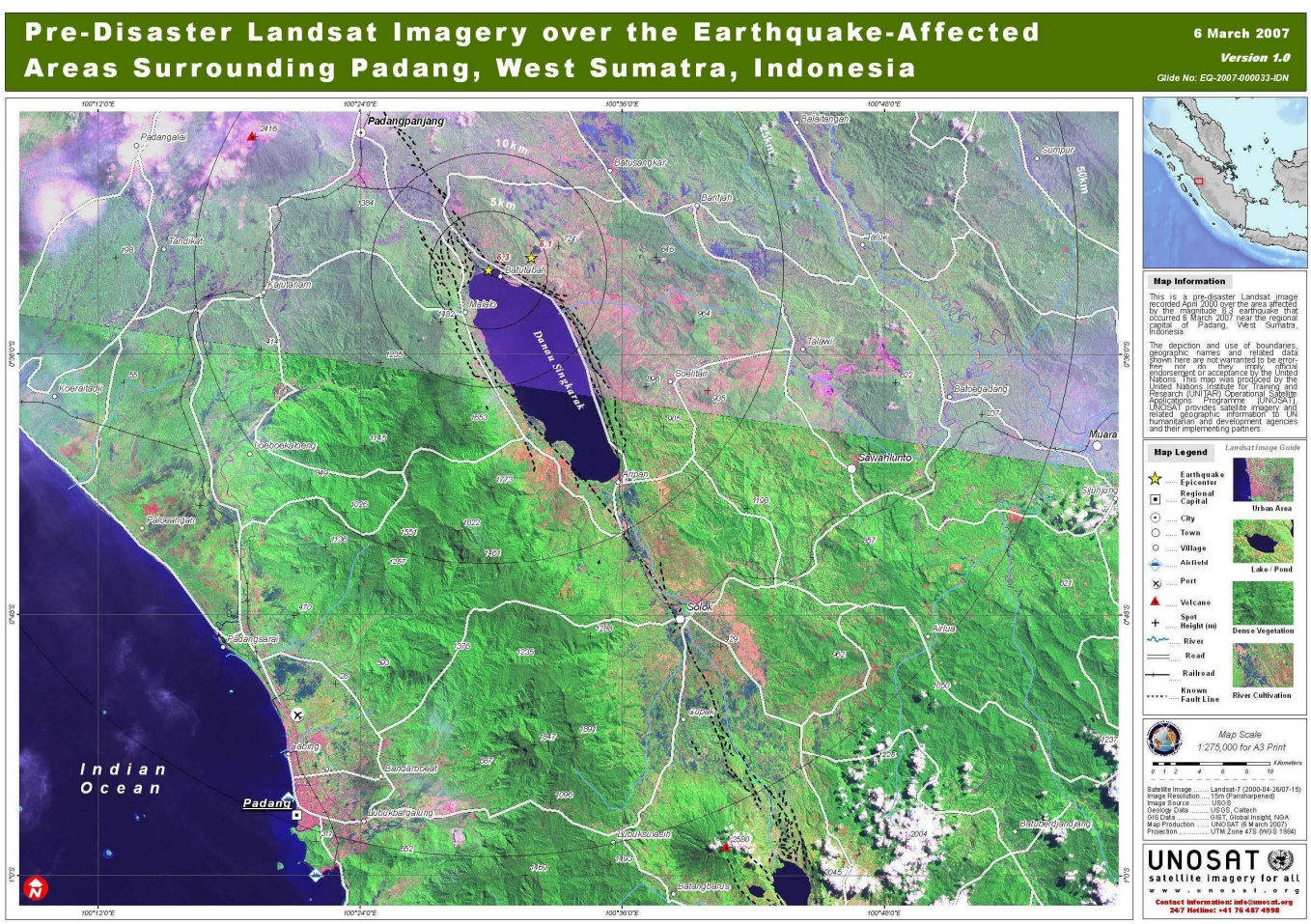


Population Density over the Earthquake-Affected Areas

Surrounding Padang, West Sumatra, Indonesia
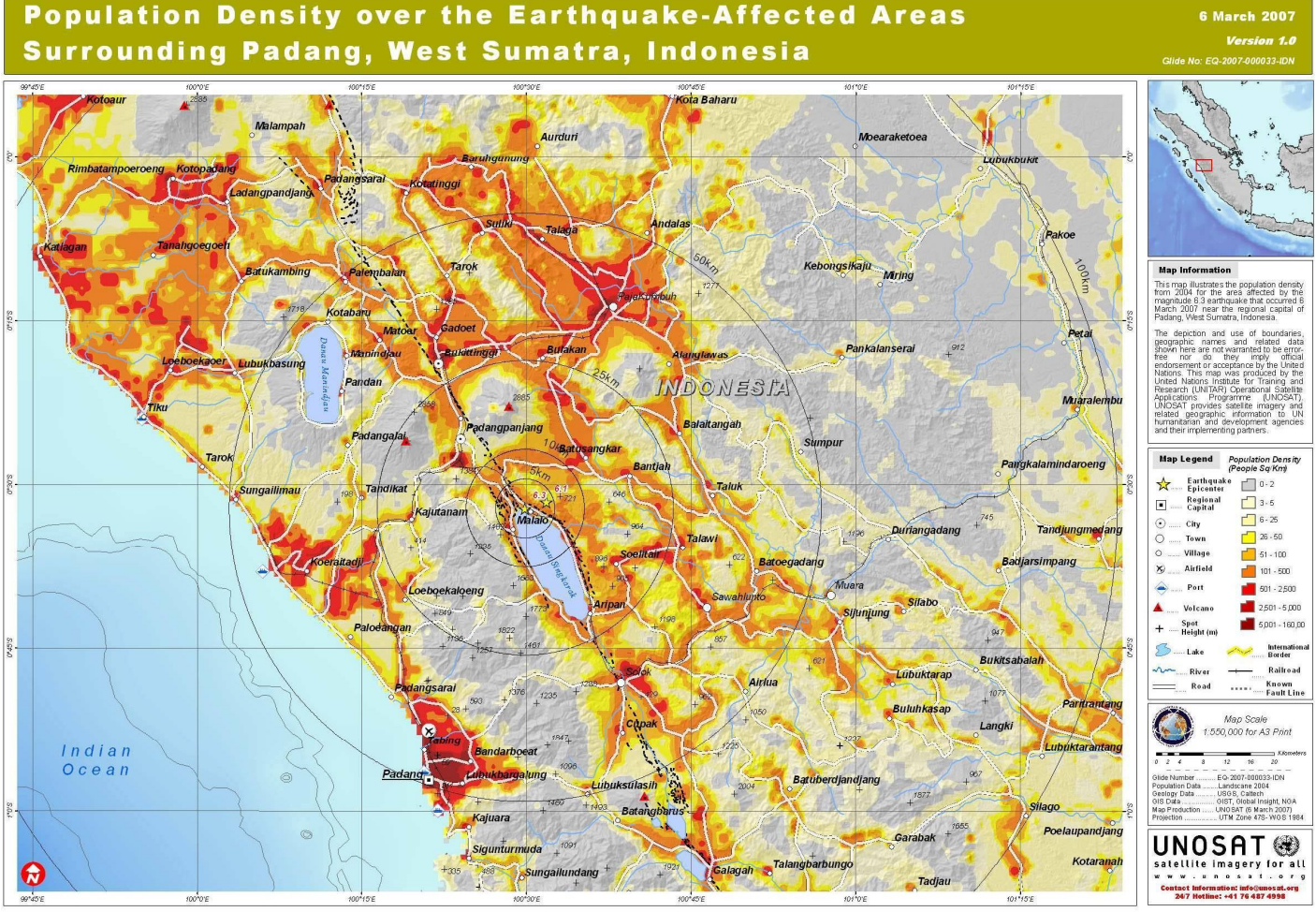

ArcView GIS 3.2

File É Edi View Iheme Graphics WWindow Help

- 回 $\mathrm{x}$

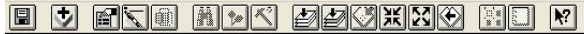

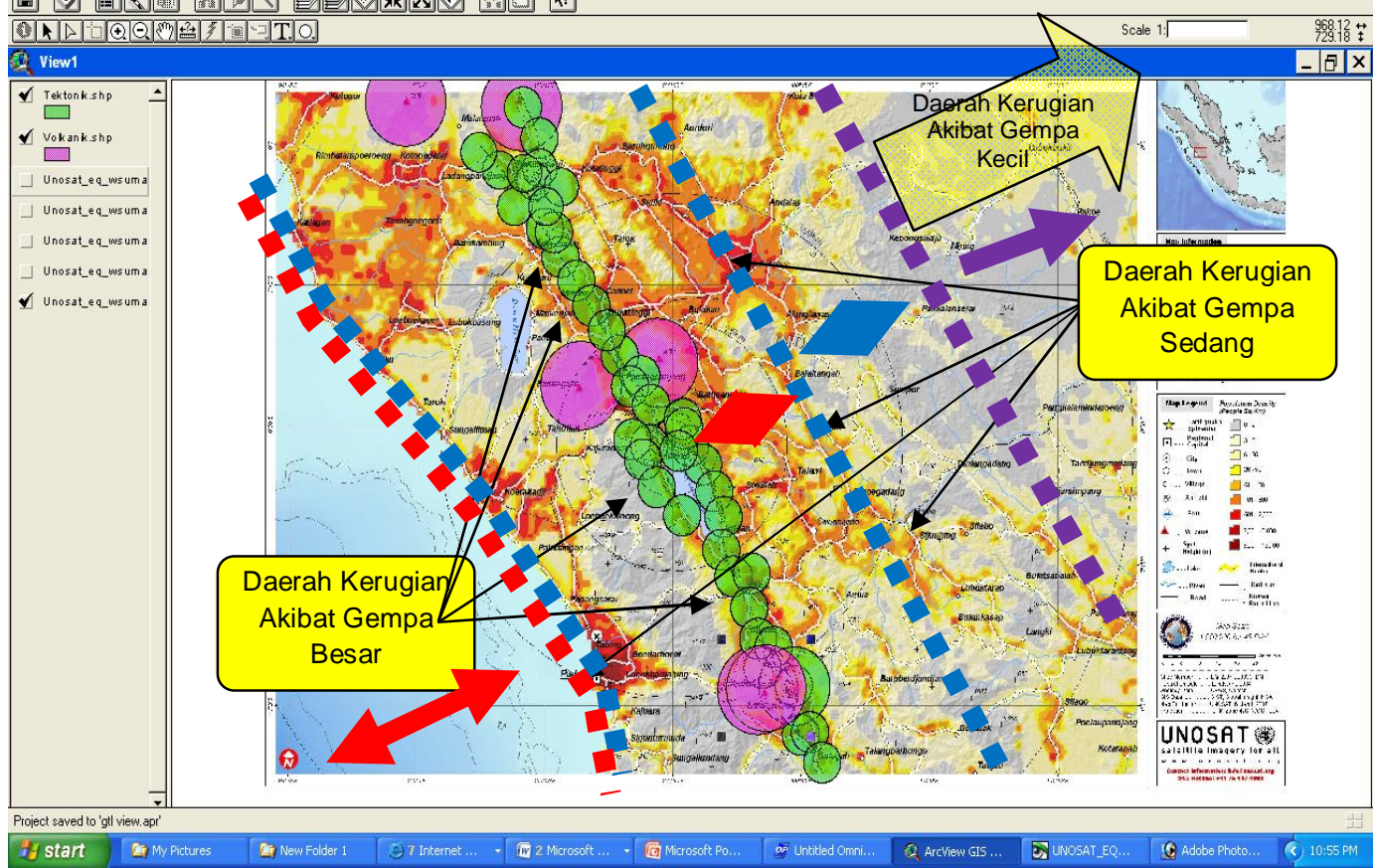

Gambar 3. Tingkat potensi kerusakan yang dirasakan manusia akibat gempa bumi 
Hasil identifikasi sesar di patahan Sumatera bagian tengah, maka dapat diketahui potensial seismik baik yang potensi akibat vulkanisme ataupun tektonisme.

Dari pola patahan linier Zona Sumatera bagian tengah yang diketahui, maka dapat memperkirakan daerah-daerah yang memerlukan penanganan khusus untuk kegiatan mitigasi bencana alam. Hal tersebut disebabkan karena daerahdaerah tersebut selain dekat dengan potensi terjadi gempa (patahan) juga mempunyai tingkat kepadatan penduduk yang tinggi. Karena tingkat kepadatan penduduk tinggi, maka gempa yang merusak sarana dan prasarana kegiatan manusia sangat dirasakan, sehingga dampak negative, seperti : korban jiwa, bangunan roboh, jalan rusak besar dan menjadikan tingkatan hazard yang tinggi. Sebaliknya, gempa dengan intensitas yang tinggi pada area dimana aktivitas manusia kurang bahkan tidak ada, maka dampak yang dirasakan manusia juga kecil, sehingga menjadikan tingkat hazard yang merusak juga kecil.

\section{Penutup}

Dari uraian singkat dapat ditarik beberapa kesimpulan, yaitu :

a. Persebaran daerah rawan gempa akibat patahan Sumatera bagian tengah adalah berada di sekitar patahan, dan besar kecilnya kerusakan yang terjadi tergantung pada Panjang, lebar, kedalaman hiposentrum gempa bumi; Jenis batuan yang terkena gempa; Besarnya pergeseran batuan (displacement); Lama dari getaran gempa

b. Daerah dengan potensial kerusakan BESAR akibat gempa bumi patahan Sumatera bagian tengah adalah pada : Solok, Padang Panjang, Bukit Tinggi,; Sedangkan Potensial kerusakan SEDANG akibat gempa bumi patahan Sumatera bagian tengah adalah pada : Muara Sijunjung, Sawah Lunto, Paya Kumbuh; Dan Potensial kerusakan KECIL akibat gempa bumi patahan Sumatera bagian tengah adalah pada : Kota/ Kabupaten di sebelah timur Muara Sijunjung, Sawah Lunto, Paya Kumbuh. Untuk kota di pesisir barat Sumatera, seperti Padang mempunyai tingkat kerawanan yang tinggi terhadap gempa bumi tektonik dari proses konvergen Lempeng Samudra Hindia dan Lempeng benua Eurasia dan gelombang tsunami yang dapat ditimbulkannya.

\section{Daftar Pustaka}

John Milsom, Geology of Sumatera (Seismology and Neotectonics) on Journal Geological Society Memoir No.27

Van Bemmelem, 1939, The Geology of Indonesia, Martinus Nijhoff, The Hague, v.1.

www.unosat.cern.web.ch, tanggal 7 Maret 2007

www.bbc.co.uk, tanggal 7 maret 2007

www.greenwood.cr.usgv.gov, tanggal 7 maret 2007 